Article

\title{
The Impacts of Domestic and Foreign Direct Investments on Economic Growth in Saudi Arabia
}

\author{
Mounir Belloumi ${ }^{1,2, * \text { (D) and Atef Alshehry }}{ }^{2}$ \\ 1 LAMIDED, University of Sousse, Sousse 4023, Tunisia \\ 2 College of Administrative Sciences, Najran University, Najran 1988, Saudi Arabia; asalshehry@nu.edu.sa \\ * Correspondence: mrbelloumi@nu.edu.sa; Tel.: +966-530-948-710
}

Received: 27 January 2018; Accepted: 22 February 2018; Published: 19 March 2018

\begin{abstract}
This paper investigates the causal links between domestic capital investment, foreign direct investment (FDI), and economic growth in Saudi Arabia over the period 1970-2015 by using the autoregressive distributed lag (ARDL) bounds testing to cointegration approach. The fully modified ordinary least squares (FMOLS), dynamic ordinary least squares (DOLS), and the canonical cointegrating regression (CCR) are employed to check the robustness of the ARDL long run estimates. The results show that in the long term there are negative bidirectional causality between non-oil GDP growth and FDI, negative bidirectional causality between non-oil GDP growth and domestic capital investment, and bidirectional causality between FDI and domestic capital investment. FDI affects negatively domestic capital investment in the short run, whereas domestic capital investment affects negatively FDI in the long run. Both finance development and trade openness affect positively non-oil GDP growth, FDI inflows and domestic capital investment in the long run. The findings are important for Saudi policy makers to undertake the effective policies that can promote and lead domestic and foreign investments to enhance economic growth in the country.
\end{abstract}

Keywords: FDI inward flows; GDP growth; non-oil GDP growth; domestic capital investment; ARDL bounds testing cointegration; Saudi Arabia

JEL Classification: C22; E22; F14

\section{Introduction}

Theoretically, there is evidence of the existence of the relationship between domestic investment (DI) and economic growth of a country (Al khatib et al. 2012). However, empirical studies focused mainly on the relationship between foreign direct investment (FDI) and economic growth (Liu et al. 2002; Khawar 2005; Sekmen 2007; Tang et al. 2008; Thangavelu et al. 2009; Adams 2009; Roy and Mandal 2012; Temiz and Gokmen 2014; Belloumi 2014; Omri and Kahouli 2014; Iamsiraroj 2016). For example, Fabry and Zeghni (2002) state that countries with outstanding growth rate are experiencing the largest FDI inflows. After the recent financial crisis, attention has turned to the impact of domestic investment on economic growth. Therefore, the primary goals of this research are to analyze the dynamic causal relationships between domestic investment, foreign direct investment and economic growth in Saudi Arabia, and to recommend strategic ways forward that will further advance Saudi Arabia's economy. The majority of prior empirical research concentrated on the idea that development is largely led by FDI instead of domestic investment, while the domestic investment could be one of the most significant causal factors in the growth of an economy, in addition to being a successful method of creating employment within an economy. According to Firebaugh (1992), domestic investment has a greater tendency to develop relationships inside domestic industries. Other than this, domestic investment has two parts to play within an economy, firstly as a significant factor in a combination of demand and expansion of a country's reserves of useful assets. Secondly, it is 
acknowledged that domestic investment has a significant influence when explaining commercial progressions. Additionally, as stated by Kowalski (2000), domestic investment is a prolific sign of the growth of an economy. Hence, domestic investment may be a way to make modern growth of the economy speedier and easier to maintain, chiefly via capital creation, productivity, developmental progress, exporting, and so on, therefore, influencing investors on a domestic level to routinely look for the best prospects for investment. In addition, Saudi Arabia has a favorable investment climate and therefore it is anticipated that economic growth will be positively influenced by the value of domestic investment.

Oil revenue has always been a vital pillar of the Saudi economy. However, in recent times, the government has sought to make the country less dependent on the petroleum industry by diversifying the other economic sectors. The investment sector has received particular attention since the implementation of the Fourth Development Plan (1985-1990). The aim of the present study is to investigate the dynamic causal relationships between domestic investment, foreign direct investment, and economic growth in Saudi Arabia over the period 1970-2015 by using the time series econometric techniques. Trade openness is included in the model as a control variable. We should specially investigate the influence that domestic investment and FDI have on Saudi Arabia's growth of GDP and non-oil GDP. The significance of this research arises out of the information that dynamic interactions amongst these macro-economic influences will have a significant impact on policy-making.

The originality of this study relies on that is the first work that investigates the three-way relationships between overall GDP growth (and non-oil GDP growth), domestic capital investment, and foreign direct investment inflows in Saudi Arabia using the ARDL models based on the endogenous growth theory. The ARDL bounds testing to cointegration framework permits to check the existence of the long relationships between the variables and the signs of their causal impacts in both short and long terms. Besides, we use the fully modified ordinary least squares (FOLS), dynamic ordinary least squares (DOLS) and CCR estimators to check the robustness of ARDL estimators.

The rest of the paper is organized as follows. In Section 2, we present a brief of literature review. Section 3 gives an overview on the data and the methodology used to analyze the relationship between economic growth (represented overall GDP growth and non-oil GDP growth), FDI inward flows, gross fixed capital formation, finance development, and trade openness for Saudi Arabia. Section 4 shows the results and their discussion. Finally, in Section 5, we conclude our paper by some policy implications.

\section{Literature Review}

There is a vast theoretical and empirical literature dealing with FDI-growth nexus in host countries. However, the empirical results have been mixed. From one side, some studies found that FDI could stimulate economic growth through spillover effects such as new technologies, capital accumulation, increased export, and human capital development (De Mello 1999; Balasubramanyam et al. 1996, 1999; Borensztein et al. 1998; Alguacil et al. 2002; Chandana and Parantap 2002; Liu et al. 2002; Akinlo 2004; Eller et al. 2005; Moses 2011; Omonkhanlen 2011; Tintin 2012; Elsadig 2012; Hussain and Haque 2016; Choi and Baek 2017; Ridzuan et al. 2017; etc.). However, on the other side, some authors found that FDI has a negative effect on economic growth in some countries (e.g., Boyd and Smith 1992; Sadik and Bolbol 2001; Durham 2004; Meschi 2006; Lensink and Morrissey 2006; Adams 2009).

The consensus in both theoretical and empirical literature is that the productivity of the FDI is contingent on initial conditions of the host country including the absorptive capacity of the host country and the degree of complementarity between domestic investment and FDI. Liu et al. (2002) analyzed the causal associations between inward FDI and economic growth in China by including trade as a control variable by using quarterly data for the period starting in 1981:1 and ending in 1997:4 and employing time series econometric techniques. They found a long-run relationship between all of the variables that are investigated and there is bidirectional causality between economic growth and FDI. Li and Liu (2005) analyzed the relationship between foreign direct investment and economic growth for a panel of 84 countries over the period 1970-1999 by using both single equation and 
simultaneous equation system techniques. Their findings showed that FDI did not directly affect economic growth, but its interaction with human capital exerted a positive effect on economic growth in developing countries, while its interaction with the technology gap exerted a negative impact.

Adams (2009) analyzed the impact of foreign direct investment and domestic investment on economic growth in Sub-Saharan Africa for the period 1990-2003. He found that FDI has a positive and significant impact on economic growth in only the OLS estimation. The results also showed that FDI exerted an initial negative effect on DI but a subsequent positive effect in later periods for the panel of countries studied. His results indicated a net crowding out effect. The author suggested that Sub-Saharan African countries need to cooperate between them and the multinational enterprises in order to design a targeted approach to FDI that should lead to economic growth in the African continent.

Lean and Tan (2011) investigated the causal relationship between DI, FDI inflows, and economic growth in Malaysia over the period 1970-2009 by employing the multivariate cointegration approach of Johansen (1995). Their findings indicated the existence of the long run relationship between the three variables. In addition, FDI affects economic growth and DI; and, there is only a unidirectional causality running from economic growth to FDI in the short run. Hence, FDI crowds in DI in Malaysia. Elsadig (2012) also found that FDI has a significant impact on economic growth in Malaysia when using quarterly data over the period 1999-2008. Omri and Kahouli (2014) studied the interrelationship among foreign direct investment, domestic capital, and economic growth in 13 MENA countries over the period of 1990 to 2010. They employed a 'growth model' framework and estimated simultaneous-equation models using the generalized method of moments. They found that there is bi-directional causality between FDI and economic growth, and there is unidirectional causal running from FDI to domestic capital for all of the countries that were investigated. However, the results of Belloumi (2014) go against those that were obtained by Omri and Kahouli (2014). In fact, Belloumi (2014) investigated the relationship between FDI, trade openness, and economic growth for Tunisia over the period 1970-2008 by using the ARDL bounds testing to cointegration. He found that the variables are cointegrated when FDI is the dependent variable. However, his findings show that FDI does not Granger cause economic growth in Tunisia. Temiz and Gokmen (2014) studied the relation between FDI inflows and economic growth in Turkey using quarterly data from 1992:1 to 2007:3 and employing the Johansen multivariate cointegration approach. Their findings showed no causal relationship between the FDI inflows and economic growth both in the short and long run. For the same country, Bayar (2014) studied the causal relationship between DI, FDI, and economic growth over the period 1980-2012 by using the bounds testing to co-integration approach. He found that the three variables are cointegrated, but the foreign direct investment inflows had a negative effect on economic growth in both short and long run. By contrast, Tahir et al. (2015) confirmed the FDI-led growth hypothesis. They studied the relationship between external determinants (e.g., foreign remittances, foreign direct investment, and foreign imports) and economic growth in Pakistan over the period 1977-2013 by using time series econometric techniques. Their main results are that foreign remittances and foreign direct investment lead to economic growth in Pakistan, whereas it is not the case for foreign imports. The authors suggested that policy makers should take appropriate decisions or strategies to increase the inflows of both foreign remittances and foreign direct investment in order to attain economic growth in the long term.

In the same line and using the same techniques based on simultaneous system of equations approach as Omri and Kahouli (2014), Iamsiraroj (2016) studied FDI-economic growth nexus for 124 cross-country data over the period 1971-2010. His empirical results indicated that overall FDI affects positively economic growth and vice versa. In addition, some determinants of FDI, such as labor force, trade openness, and economic freedom stimulated economic growth. Hussain and Haque (2016) studied the relationship between FDI inflows, trade openness and economic growth for Bangladesh over the period 1973-2014 using the multivariate cointegration approach. They found that both FDI inflows and trade openness have significant effects on economic growth. Because FDI and trade are 
two important components of economic growth in Bangladesh, it is important to frame policies that promote growth and reduce the barriers for capital flows. Choi and Baek (2017) reported that FDI inflows lead to improve TFP growth in India through positive spillover effects. Using the ARDL technique, Ridzuan et al. (2017) found that FDI inflows play an important role in increasing economic growth in Singapore over the period 1970-2013.

In the other side, the relationship between domestic investment and economic growth has been reported by many empirical studies. These include Ghali and Al-Mutawa (1999); Ghirmay et al. (2001); Villa (2008); Adams (2009); Ruranga et al. (2014). Nonetheless, the outcome of such studies concerning the relationship between DI and the economic growth does not consistently reach unanimity. Ghali and Al-Mutawa (1999) carried out a time series analysis on G-7 countries and found that each country exhibits a different relationship between fixed capital formation and economic growth, which can be mutually influential. Dritsaki et al. (2004) studied the relationship between investments and economic growth by including exports as additional variable in the three Baltic countries for trimestral data over the period 1992:1-2000:4 by employing the cointegration approach developed by Johansen and Juselius (1990). They found that investments positively affected economic growth of the three Baltic countries. Later, Qin et al. (2006) demonstrated that the direction of causation was from the economic growth to DI, rather than the other way around. However, Villa (2008) found that DI causes economic growth in the case of Italy over the period 1950-2005 by using the Johansen multivariate cointegration technique. Tang et al. (2008) studied the relationship between economic growth, FDI, and DI in China during the period of 1988 to 2003 using the multivariate cointegration approach. Their results showed that DI has a more pronounced effect on economic growth than FDI in China. The authors suggested that China should prioritize fostering national savings for national investment rather than inviting FDI. In the same line, Adams (2009) found that DI has a positive and significant impact on economic growth for Sub-Saharan African countries. Lean and Tan (2011) found that DI has a negative impact on economic growth in the long term in Malaysia.

Omri and Kahouli (2014) found also that there is bi-directional causality between domestic capital and economic growth in all the 13 MENA countries that were studied, including Saudi Arabia. In contrast, Bayar (2014) found that DI has a significant positive effect on economic growth in both the short and long run in Turkey. Iya and Aminu (2015) investigated the influence of foreign direct investment and domestic investment on economic growth in Nigeria over the period 1992-2013. The authors found a positive and significant relationship between economic growth and domestic investment.

\section{Data and Methods}

This study is based on the new theory of endogenous growth initially developed by Arrow (1962) and Shell (1966) and later extended by Romer (1986, 1990), Lucas (1988), and Grossman and Helpman (1994). The investigation of the relationship between DI, FDI, finance development, trade openness, and economic growth is based on the standard model of growth where economic output is determined by total factor productivity and the conventional inputs. However, the new theory of endogenous growth states that total factor productivity is determined endogenously by economic factors, such as FDI inflows and technological progress (Belloumi 2014). According to the literature on the FDI-led growth hypothesis (see De Mello 1997; Borensztein et al. 1998; Ozturk 2007), FDI may promote knowledge transfers through labor training and skill acquisition and by the adoption of new management practices and better organizational arrangements.

\subsection{Data Descriptions}

The study is based on annual time series data representing economic growth, gross fixed capital formation, inward FDI flows, trade openness, and finance development covering the period 1970 to 2015. The data are obtained from the Saudi Arabian Monetary Agency (SAMA), the United Nations Conference on Trade and Development (UNCTAD 2016), and the World Development Indicators (WDI) published online by the World Bank (World Bank 2016). The data corresponding to inward 
FDI flows (FDI) are obtained from UNCTAD online database. The data corresponding to finance development (FD), trade openness (TO), and real gross fixed capital formation (GFCF) are sourced from WDI. The data corresponding to real GDP growth and real non-oil GDP growth are sourced from SAMA. Overall economic growth (GGDP) is measured by the GDP growth at constant prices $(2010=100)$. Real non-oil GDP growth (GNOG) is measured by the non-oil GDP growth at constant prices $(2010=100)$. As an oil exporter country, Saudi Arabia should not rely on the oil sector as an indicator of growth because despite its important contribution to the total GDP, inconsistencies in global oil prices have a substantial influence on it. Thus, we also use the GDP of non-oil sector as a proxy for economic growth in Saudi Arabia (GNOG). Domestic investment is measured by the value of gross fixed capital formation to GDP ratio. GFCF is involved with the fluctuations that materialize concerning tangible assets (in a pre-defined window of time) that are associated with a country's economy. Such assets are usually those that are advantageous in positively progressing the country, for example, the development of structures, road building, more institutions that are educational, improved transport or transmission links, hospitals, commercial buildings, estates, or domestic homes. Within a pre-defined timescale, determining the GFCF of a country is essential to pinpoint the GDP. Inward FDI flows are the value of real foreign direct investment inflows to GDP ratio. We use this approximation, as it is available for a reasonable period from 1970 to 2015. Trade openness is measured by the sum of exports and imports divided by GDP. Finance development is approached by domestic credit to private sector to GDP ratio. The descriptive statistics of all these variables at their levels are reported in Table 1.

Table 1. Descriptive statistics of the variables.

\begin{tabular}{ccccccc}
\hline Variables & GGDP & GNOG & GFCF & FDI & FD & TO \\
\hline $\begin{array}{c}\text { Variables } \\
\text { Description }\end{array}$ & $\begin{array}{c}\text { GDP } \\
\text { Growth }\end{array}$ & $\begin{array}{c}\text { Non-Oil } \\
\text { GDP } \\
\text { Growth }\end{array}$ & $\begin{array}{c}\text { Gross Fixed } \\
\text { Capital Formation } \\
\text { (\% of GDP) }\end{array}$ & $\begin{array}{c}\text { Inward FDI } \\
\text { Flows } \\
\text { (\% of GDP) }\end{array}$ & $\begin{array}{c}\text { Domestic Credit } \\
\text { to Private Sector } \\
\text { (\% of GDP) }\end{array}$ & $\begin{array}{c}\text { Trade } \\
\text { (\% of GDP) }\end{array}$ \\
\hline Mean & 4.398 & 6.128 & 20.592 & 1.159 & 21.468 & 77.927 \\
Median & 3.565 & 4.845 & 20.558 & 0.382 & 20.754 & 75.831 \\
Maximum & 24.170 & 38.620 & 29.990 & 8.496 & 56.632 & 120.619 \\
Minimum & -20.730 & -5.200 & 8.834 & -8.218 & 2.750 & 56.474 \\
Std. Dev. & 9.537 & 6.951 & 4.395 & 2.960 & 13.524 & 12.538 \\
Obs. & 46 & 46 & 46 & 46 & 46 & 46 \\
\hline
\end{tabular}

\subsection{Methodology}

The methodology used in this study is based on time series econometric techniques. There are two important steps of the econometric methodology applied here. The first step involves the establishment of the integration order of the variables incorporated in the models by employing unit root tests, such as the augmented Dickey-Fuller (ADF) test, the Phillips-Perron (PP) test, and the Generalized Least Squares and Dickey-Fuller test (DF-GLS) test that is developed by Elliott et al. (1996). The purpose of using three unit root techniques is to compensate for the low power of these tests. They are used to guarantee the validity of the results, which may potentially be affected by the limited size of the samples employed. The second step entails the application of co-integration methods. More specifically, the relationship between the variables used in the short and long-term should be analyzed by employing the Johansen multivariate cointegration approach or the autoregressive distributed lag model and the bounds testing of cointegration of Pesaran and Shin (1999). Moreover, to our knowledge, until now none of the studies that test the impact of FDI, domestic investment, finance development, and trade openness on both overall economic growth and non-oil GDP growth in the case of Saudi Arabia.

As the results of unit root tests show that all the variables are integrated of order zero or one, we use the ARDL models and bounds testing for cointegration approach to check for the presence of long run relationships between the variables that were investigated. 


\subsubsection{ARDL Bounds Testing Cointegration}

Our study is based on ARDL models and bounds testing for cointegration approach, which is developed by Pesaran and Shin (1999) and Pesaran et al. (2001). These models are recently used to test for the presence of long-run relationships between the different macroeconomic variables. The main advantage of this approach is that it does not need that all of the variables are integrated of the same order. It requires that the time series are either integrated of order zero or one or fractionally integrated.

The implementation of the ARDL method implies three steps. In the first step, we check for the order of integration of the various variables investigated by using the unit root tests of ADF (Dickey and Fuller 1979), PP (Phillips and Perron 1988), and DF-GLS (Elliott et al. 1996). We use three tests to check for the robustness of the results. The DF-GLS test is more efficient when we deal with variables of small size.

In the second step, we estimate the following unrestricted error-correction models given by Equations (1)-(4):

$$
\begin{gathered}
\Delta G G D P_{t}=\beta_{0}+\sum_{i=1}^{p} \beta_{i} \Delta G G D P_{t-i}+\sum_{j=0}^{q_{1}} \gamma_{j} \Delta F D I_{t-j}+\sum_{j=0}^{q_{2}} \delta_{j} \Delta G F C F_{t-j}+\sum_{j=0}^{q_{3}} \mu_{j} \Delta F D_{t-j}+ \\
\sum_{j=0}^{q_{4}} \lambda_{j} \Delta T O_{t-j}+\theta_{0} G G D P_{t-1}+\theta_{1} F D I_{t-1}+\theta_{2} G F C F_{t-1}+\theta_{3} F D_{t-1}+\theta_{4} T O_{t-1}+\varepsilon_{t} \\
\Delta G N O G_{t}=\beta_{0}+\sum_{i=1}^{p} \beta_{i} \Delta G N O G_{t-i}+\sum_{j=0}^{q_{1}} \gamma_{j} \Delta F D I_{t-j}+\sum_{j=0}^{q_{2}} \delta_{j} \Delta G F C F_{t-j}+\sum_{j=0}^{q_{3}} \mu_{j} \Delta F D_{t-j}+ \\
\quad \sum_{j=0}^{q_{4}} \lambda_{j} \Delta T O_{t-j}+\theta_{0} G N O G_{t-1}+\theta_{1} F D I_{t-1}+\theta_{2} G F C F_{t-1}+\theta_{3} F D_{t-1}+\theta_{4} T O_{t-1}+\varepsilon_{t} \\
\Delta F D I_{t}=\beta_{0}+\sum_{i=1}^{p} \beta_{i} \Delta F D I_{t-i}+\sum_{j=0}^{q_{1}} \gamma_{j} \Delta G G D P_{t-j}+\sum_{j=0}^{q_{2}} \delta_{j} \Delta G F C F_{t-j}+\sum_{j=0}^{q_{3}} \mu_{j} \Delta F D_{t-j}+ \\
\sum_{j=0}^{q_{4}} \lambda_{j} \Delta T O_{t-j}+\theta_{0} G G D P_{t-1}+\theta_{1} F D I_{t-1}+\theta_{2} G F C F_{t-1}+\theta_{3} F D_{t-1}+\theta_{4} T O_{t-1}+\varepsilon_{t} \\
\Delta G F C F_{t}=\beta_{0}+\sum_{i=1}^{p} \beta_{i} \Delta G F C F_{t-i}+\sum_{j=0}^{q_{1}} \gamma_{j} \Delta F D I_{t-j}+\sum_{j=0}^{q_{2}} \delta_{j} \Delta G G D P_{t-j}+\sum_{j=0}^{q_{3}} \mu_{j} \Delta F D_{t-j}+ \\
\quad \sum_{j=0}^{q_{4}} \lambda_{j} \Delta T O_{t-j}+\theta_{0} G G D P_{t-1}+\theta_{1} F D I_{t-1}+\theta_{2} G F C F_{t-1}+\theta_{3} F D_{t-1}+\theta_{4} T O_{t-1}+\varepsilon_{t}
\end{gathered}
$$

The second unrestricted error correction model is estimated by replacing the variable overall GDP growth by the variable non-oil GDP growth. The lags $\mathrm{p}, \mathrm{q}_{1}, \mathrm{q}_{2}, \mathrm{q}_{3}$, and $\mathrm{q}_{4}$ are chosen based on the Akaike information criterion (AIC). All of the tests of stability, normality, autocorrelation, and heteroskedasticity should be used to check the models estimated. Besides that, we implement the Bounds test by testing the hypothesis, $H_{0}: \theta_{0}=\theta_{1}=\theta_{2}=\theta_{3}=\theta_{4}=0$ against $H_{1}: \theta_{0} \neq 0, \theta_{1} \neq 0, \theta_{2} \neq 0, \theta_{3} \neq 0, \theta_{4} \neq 0$ for each model. The rejection of the null hypothesis implies the presence of a cointegrating relationship between the variables. The decision rule is based on the F-test, developed by Wald. The critical values for the F-test are provided by Pesaran et al. (2001), and are complemented by Narayan (2005) for smaller and finite samples. There are two critical values: one is called lower and the other is upper. The lower is determined by considering that all of the series are stationary, whereas the upper is determined by considering that all of the variables are integrated of order one. Their values are dependent on the sample size, the number of the independent variables and probability levels. The null hypothesis is rejected when the value of the F-statistic exceeds the upper critical value. In this case, the variables are cointegrated. However, when the value of the F-statistic is inferior to the lower critical value, we accept the null hypothesis and we conclude that the variables are not cointegrated. Lastly, when the F-statistic lies between both critical values, we cannot conclude (Belloumi and Alshehry 2015). 


\subsubsection{Long Run Granger Causality Test}

When the results show that the variables are cointegrated, we estimate the long-run relationship equations, as well as the restricted error correction models given by Equations (5)-(8) to determine the dynamics of the short-run and the speed of adjustment (Belloumi and Alshehry 2015):

$$
\begin{gathered}
\Delta G G D P_{t}=\beta_{0}+\sum_{i=1}^{p} \beta_{i} \Delta G G D P_{t-i}+\sum_{j=0}^{q_{1}} \gamma_{j} \Delta F D I_{t-j}+\sum_{j=0}^{q_{2}} \delta_{j} \Delta G F C F_{t-j}+\sum_{j=0}^{q_{3}} \mu_{j} \Delta F D_{t-j}+ \\
\sum_{j=0}^{q_{4}} \lambda_{j} \Delta T O_{t-j}+\pi E C T_{t-1}+\varepsilon_{t} \\
\Delta G N O G_{t}=\beta_{0}+\sum_{i=1}^{p} \beta_{i} \Delta G N O G_{t-i}+\sum_{j=0}^{q_{1}} \gamma_{j} \Delta F D I_{t-j}+\sum_{j=0}^{q_{2}} \delta_{j} \Delta G F C F_{t-j}+\sum_{j=0}^{q_{3}} \mu_{j} \Delta F D_{t-j}+ \\
\sum_{j=0}^{q_{4}} \lambda_{j} \Delta T O_{t-j}+\pi E C T_{t-1}+\varepsilon_{t} \\
\Delta F D I_{t}=\beta_{0}+\sum_{i=1}^{p} \beta_{i} \Delta F D I_{t-i}+\sum_{j=0}^{q_{1}} \gamma_{j} \Delta G G D P_{t-j}+\sum_{j=0}^{q_{2}} \delta_{j} \Delta G F C F_{t-j}+\sum_{j=0}^{q_{3}} \mu_{j} \Delta F D_{t-j}+ \\
\sum_{j=0}^{q_{4}} \lambda_{j} \Delta T O_{t-j}+\pi E C T_{t-1}+\varepsilon_{t} \\
\Delta G F C F_{t}=\beta_{0}+\sum_{i=1}^{p} \beta_{i} \Delta G F C F_{t-i}+\sum_{j=0}^{q_{1}} \gamma_{j} \Delta F D I_{t-j}+\sum_{j=0}^{q_{2}} \delta_{j} \Delta G G D P_{t-j}+\sum_{j=0}^{q_{3}} \mu_{j} \Delta F D_{t-j}+ \\
\sum_{j=0}^{q_{4}} \lambda_{j} \Delta T O_{t-j}+\pi E C T_{t-1}+\varepsilon_{t}
\end{gathered}
$$

when the variables are cointegrated, we test for long run causality between the dependent variable and the explanatory variables in each restricted error correction model. The negative sign and the significance of the coefficient $(\pi)$ of the error correction term confirm the presence of long run causality from the independent variables to the dependent variable.

\section{Empirical Results and Discussion}

\subsection{Results of Unit Root Tests}

\subsubsection{Results of Conventional Unit Root Tests}

As stated before, we begin by checking the order of integration of the different variables by applying the ADF, PP, and DF-GLS tests. The results of the three unit root tests are reported in Table 2. We find that the three variables of GDP growth, non-oil GDP growth, and FDI are stationary at their levels, whereas the variables of GFCF and FD are not stationary at their levels but are stationary at their first differences. The variable TO is found not stationary at its level only by the ADF test whereas it becomes stationary at its first difference. Approximately, all the three tests report the same results, which confirm the robustness of our results. We can conclude that none of the variables is integrated of order two. 
Table 2. Results of conventional unit root tests.

\begin{tabular}{cccc}
\hline Variables & ADF & PP & DF-GLS \\
\hline GGDP & $-4.38(0)^{*}$ & $-4.30(2)^{*}$ & $-2.60(0)^{* *}$ \\
GNOG & $-2.05(0)^{* *}$ & $-2.16(1)^{* *}$ & $-2.79(0)^{*}$ \\
GFCF & $-2.14(0)$ & $-2.16(3)$ & $-1.30(0)$ \\
FDI & $-3.12(0)^{*}$ & $-3.13(3)^{*}$ & $-3.38(0)^{*}$ \\
FD & $2.43(0)$ & $3.47(6)$ & $1.44(0)$ \\
TO & $-2.07(1)$ & $-3.16(3)^{* *}$ & $-2.01(1)^{* *}$ \\
$\Delta$ GFCF & $-6.12(0)^{*}$ & $-6.10(4)^{*}$ & $-5.85(0)^{*}$ \\
$\Delta$ FD & $-5.14(0)^{*}$ & $-4.71(5)^{*}$ & $-5.15(0) *$ \\
$\Delta$ TO & $-10.33(0)^{*}$ & $-10.45(2)^{*}$ & $-10.24(0) *$
\end{tabular}

Notes: The asterisks * and ** denote the significance at the $1 \%$ and $5 \%$ levels, respectively. The optimal lag orders for augmented Dickey-Fuller (ADF) and Dickey-Fuller Generalized Least Squares and test (DF-GLS) tests are determined using the Schwarz criterion, while the bandwidth for Phillips-Perron (PP) test is determined by the Newey-West using Bartlett kernel. The values between parentheses are the maximum lag length used in computing the tests.

\subsubsection{Results of Breakpoint Unit Root Tests}

As the conventional unit root tests are biased when there is a trend stationary with an exogenous structural break (Perron 1989), we use the Perron breakpoint unit root tests to take into account the structural change in the variables (for more details on these tests, see (Belloumi and Alshehry 2016). ${ }^{1}$

The results of the Perron breakpoint unit root tests are reported in Table 3. It is clearly shown that they give the same results as the conventional unit root tests. The three variables of GDP growth, non-oil GDP growth, and FDI are integrated of order zero, whereas the variables of GFCF, TO, and FD are integrated of order one. Therefore, the results of conventional unit root tests are robust.

Table 3. Results of Perron breakpoint unit root tests.

\begin{tabular}{|c|c|c|c|c|c|c|c|c|c|}
\hline Variables & Break & Lag & Intercept & $\begin{array}{l}\text { INCPT } \\
\text { BREAK }\end{array}$ & TREND & $\begin{array}{l}\text { TREND } \\
\text { BREAK }\end{array}$ & $\begin{array}{c}\text { BREAK } \\
\text { DUM }\end{array}$ & $\begin{array}{c}\text { ADF } \\
\text { Test } \\
\text { Statistic }\end{array}$ & $\begin{array}{l}\text { Order of } \\
\text { Integration }\end{array}$ \\
\hline GGDP & 1985 & 0 & $\begin{array}{l}31.10 \\
(0.00)\end{array}$ & $\begin{array}{l}20.85 \\
(0.00)\end{array}$ & $\begin{array}{l}-3.26 \\
(0.00)\end{array}$ & $\begin{array}{c}3.17 \\
(0.00)\end{array}$ & $\begin{array}{c}-17.06 \\
(0.00)\end{array}$ & $\begin{array}{c}-8.26 \\
{[-5.17]}\end{array}$ & $\mathrm{I}(0)$ \\
\hline GFCF & 2006 & 0 & $\begin{array}{c}5.18 \\
(0.01)\end{array}$ & $\begin{array}{c}1.17 \\
(0.10)\end{array}$ & - & - & $\begin{array}{l}-0.84 \\
(0.76)\end{array}$ & $\begin{array}{c}-2.60 \\
{[-4.44]}\end{array}$ & $\mathrm{I}(1)$ \\
\hline FDI & 2001 & 9 & $\begin{array}{c}2.29 \\
(0.00)\end{array}$ & - & $\begin{array}{l}-0.10 \\
(0.01)\end{array}$ & $\begin{array}{c}0.49 \\
(0.00)\end{array}$ & - & $\begin{array}{c}-5.94 \\
{[-4.52]}\end{array}$ & $\mathrm{I}(0)$ \\
\hline FD & 2015 & 1 & $\begin{array}{c}0.09 \\
(0.89)\end{array}$ & - & $\begin{array}{c}0.61 \\
(0.00)\end{array}$ & $\begin{array}{l}12.07 \\
(0.00)\end{array}$ & - & $\begin{array}{c}-4.32 \\
{[-4.52]}\end{array}$ & $\mathrm{I}(1)$ \\
\hline TO & 1995 & 1 & $\begin{array}{l}63.17 \\
(0.00) \\
\end{array}$ & - & $\begin{array}{l}-1.01 \\
(0.00)\end{array}$ & $\begin{array}{c}1.79 \\
(0.00) \\
\end{array}$ & - & $\begin{array}{c}-3.85 \\
{[-4.52]}\end{array}$ & $\mathrm{I}(1)$ \\
\hline GNOG & 1985 & 0 & $\begin{array}{l}13.73 \\
(0.00)\end{array}$ & - & $\begin{array}{l}-0.98 \\
(0.00)\end{array}$ & $\begin{array}{c}1.14 \\
(0.00)\end{array}$ & - & $\begin{array}{c}-4.72 \\
{[-4.52]}\end{array}$ & $\mathrm{I}(0)$ \\
\hline
\end{tabular}

Notes: Numbers in (.) and [.] are respectively probabilities and 5\% critical values.

\subsection{Results of ARDL Models}

As we find that all of the variables are $\mathrm{I}(0)$ or $\mathrm{I}(1)$, we cannot use the Johansen multivariate cointegration approach, but we can use the ARDL bounds testing to cointegration method. In doing so, we estimate the four ARDL models given by Equations (1)-(4). The four models are estimated by

1 We consider here an "innovational outlier" breakpoint. 
including a dummy variable for each break that takes the value "zero" before the breakpoint date, and the value "one" after. However, we retain at the end only the dummies that are statistically significant at the $5 \%$ level of significance.

The models selection criterion used is AIC. The results of models selection criteria are reported in Table 4.

Table 4. Results of models selection criteria.

\begin{tabular}{ccccc}
\hline ARDL Model & AIC & SIC & HQ & Specification \\
\hline ARDL(GGDP/ GFCF, FDI, FD, TO) & 6.49 & 7.48 & 6.86 & ARDL $(2,4,4,4,4)$ \\
ARDL (GNOG / GFCF, FDI, FD, TO) & 3.98 & 5.02 & 4.36 & ARDL $(5,4,3,2,5)$ \\
ARDL(GFCF / GNOG, FDI, FD, TO) & 3.11 & 4.15 & 3.49 & ARDL $(2,5,2,3,5)$ \\
ARDL (FDI/ GFCF, GNOG, FD, TO) & 3.24 & 4.11 & 3.56 & ARDL $(1,5,5,0,4)$ \\
\hline
\end{tabular}

The results of diagnostic tests applied to the four models are shown in Table 5. The results of Jarque-Bera normality, Breusch-Godfrey serial correlation LM, ARCH, and Breusch-Pagan-Godfrey tests report that the error terms are normally distributed, serially independent, and homoscedastic at the $5 \%$ level of significance in the four models given by Equations (1)-(4). Finally, the results of CUSUM and CUSUM of Squares tests are shown, respectively, in Figures 1-4 for the first equation of overall GDP growth and the second equation of non-oil GDP growth. It is shown that the estimated line is lying between both critical limits at the 5\% significance level in all of the figures. Therefore, the coefficients of the models are dynamically stables. The results of CUSUM and CUSUM of Squares tests for the ARDL models given in Equations (3)-(4) are not reported here to conserve space but they are available upon request. Hence, we can conclude that our ARDL models are reliable.

Table 5. Results of diagnostic tests.

\begin{tabular}{|c|c|c|c|c|c|c|c|c|}
\hline \multirow[t]{2}{*}{ Models } & \multicolumn{2}{|c|}{$\begin{array}{c}\text { Breusch-Godfrey } \\
\text { LM Test }\end{array}$} & \multicolumn{2}{|c|}{ Normality Test } & \multicolumn{2}{|c|}{$\begin{array}{c}\text { Breusch-Pagan-Godfrey } \\
\text { Test }\end{array}$} & \multicolumn{2}{|c|}{ y ARCH Test } \\
\hline & LM Stat & $p$-Value & J-B Stat & $p$-Value & $X^{2}$ Stat & $p$-Value & $X^{2}$ Stat & $p$-Value \\
\hline \multirow{2}{*}{$\begin{array}{c}\mathrm{F}_{G G D P}(\mathrm{GGDP} / \mathrm{GFCF}, \\
\text { FDI, FD, TO })\end{array}$} & [1] 3.76 & 0.06 & \multirow{2}{*}{0.16} & \multirow{2}{*}{0.91} & \multirow{2}{*}{23.64} & \multirow{2}{*}{0.42} & [1] 0.89 & 0.34 \\
\hline & [2] 3.77 & 0.15 & & & & & [2] 2.41 & 0.29 \\
\hline \multirow{2}{*}{$\begin{array}{c}\mathrm{F}_{\text {GNOG }}(\mathrm{GNOG} / \mathrm{GFCF}, \\
\text { FDI, FD, TO) }\end{array}$} & [1] 0.84 & 0.35 & \multirow{2}{*}{13.38} & \multirow{2}{*}{0.01} & \multirow{2}{*}{18.34} & \multirow{2}{*}{0.78} & [1] 2.26 & 0.13 \\
\hline & [2] 0.89 & 0.63 & & & & & [2] 2.94 & 0.22 \\
\hline \multirow{2}{*}{$\begin{array}{c}\mathrm{F}_{G F C F}(\mathrm{GFCF} / \mathrm{GNOG}, \\
\text { FDI, FD, TO })\end{array}$} & [1] 0.15 & 0.69 & \multirow{2}{*}{0.56} & \multirow{2}{*}{0.75} & \multirow{2}{*}{27.98} & \multirow{2}{*}{0.26} & [1] 0.01 & 0.90 \\
\hline & [2] 2.16 & 0.33 & & & & & [2] 0.47 & 0.79 \\
\hline $\mathrm{F}_{F D I}(\mathrm{FDI} / \mathrm{GFCF}$, & [1] 3.56 & 0.06 & \multirow{2}{*}{1.22} & \multirow{2}{*}{0.54} & \multirow{2}{*}{21.11} & \multirow{2}{*}{0.39} & [1] 0.04 & 0.84 \\
\hline GNOG, FD, TO) & [2] 3.63 & 0.16 & & & & & [2] 0.02 & 0.99 \\
\hline
\end{tabular}

Notes: The values between bracket [.] denote the order of the diagnostic tests.

Since all of the ARDL models, given by Equations (1)-(4), pass all of the diagnostic tests without problem; we test for the existence of long run relationships by using the Bounds test. Results of the test for the four models are reported in Table 6. They indicate that there is a long run relationship between overall GDP growth and the various explanatory variables (foreign direct investment inflows, gross fixed capital formation, finance development, and trade openness) at a $5 \%$ level of significance. In addition, a long run relationship between the non-oil GDP growth and the various explanatory variables (foreign direct investment, gross fixed capital formation, finance development and trade openness) at a $1 \%$ level of significance is present. A cointegrating relationship between domestic capital investment and the various explanatory variables (foreign direct investment, non-oil GDP growth, finance development, and trade openness) at a 1\% level of significance is reported. Finally, a cointegrating relationship between foreign direct investment and the various explanatory variables 
(domestic capital investment, non-oil GDP growth, finance development, and trade openness) at a 5\% level of significance is shown.

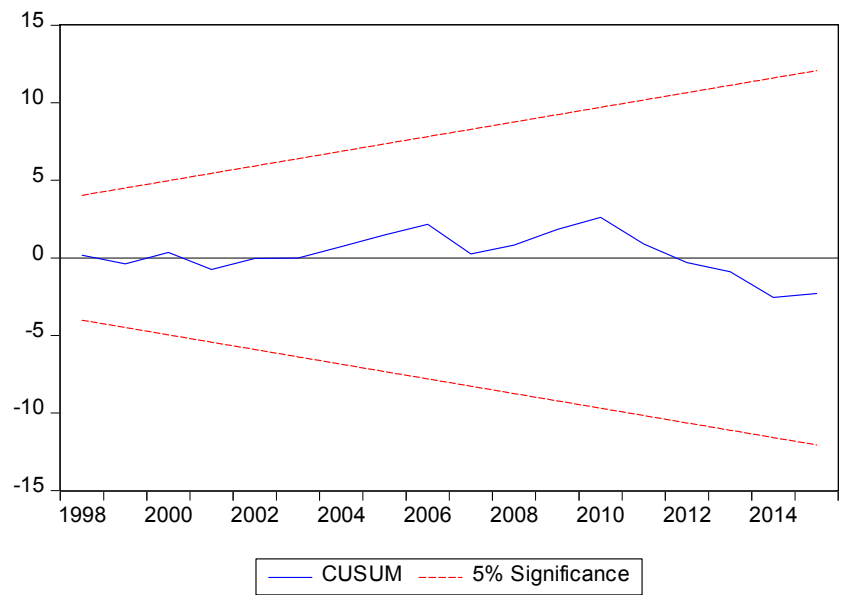

Figure 1. Results of CUSUM test for the ARDL $(2,4,4,4,4)$ model.

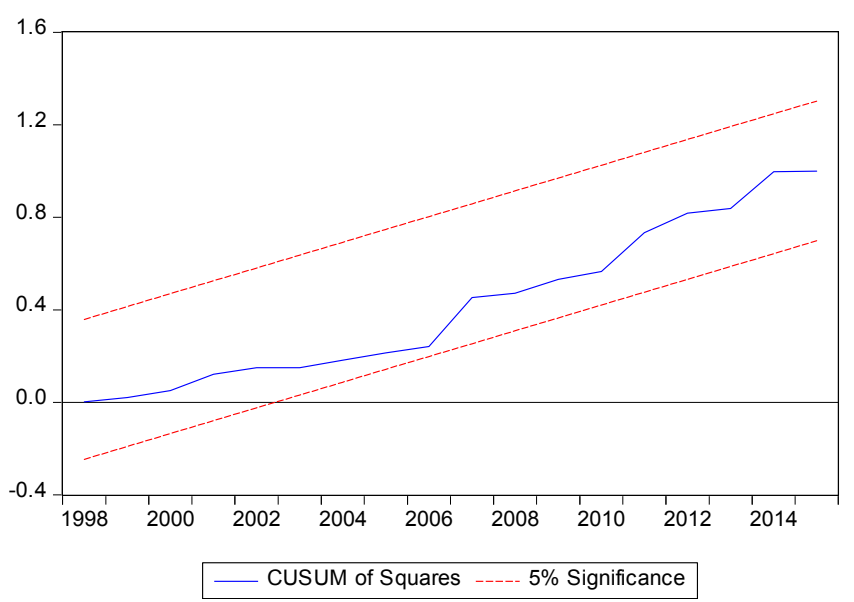

Figure 2. Results of CUSUM of Squares test for the ARDL $(2,4,4,4,4)$ model.

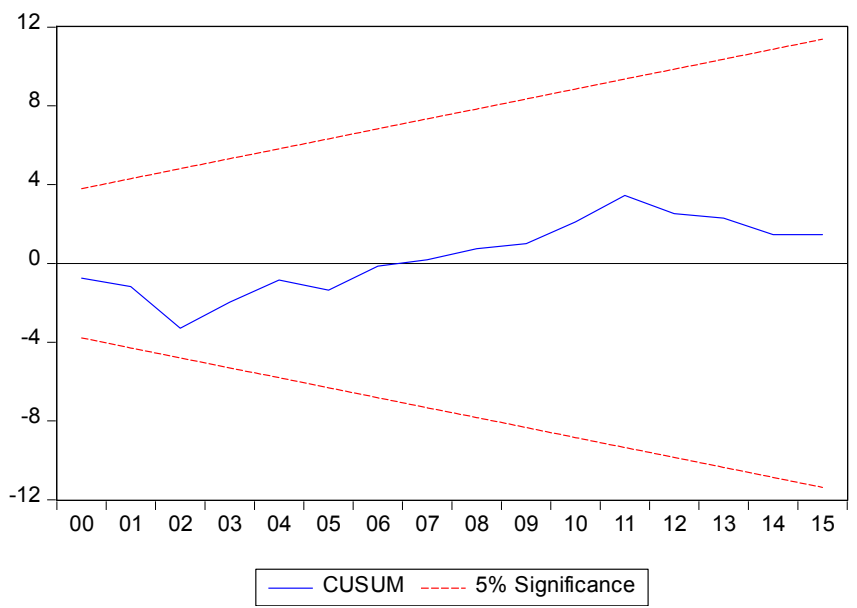

Figure 3. Results of CUSUM test for the ARDL $(5,4,3,2,5)$ model. 


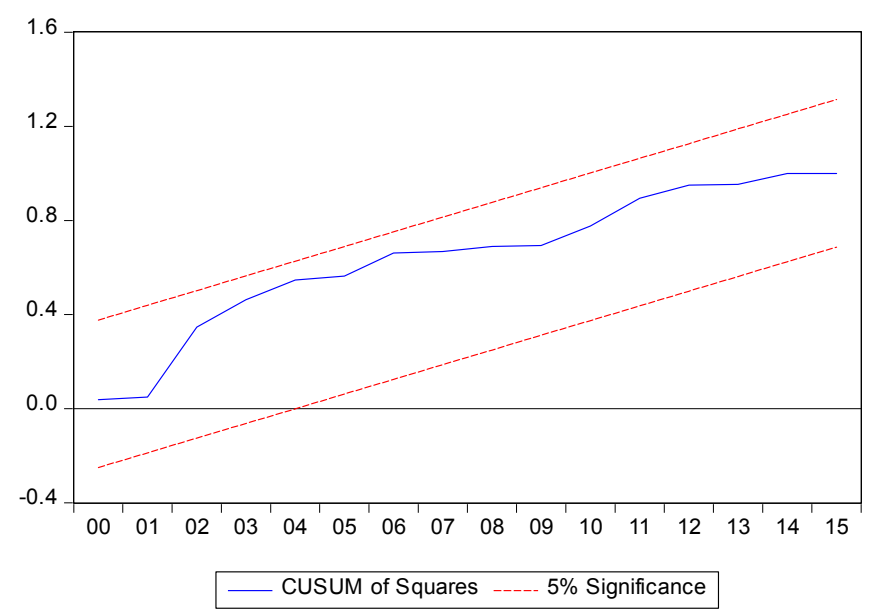

Figure 4. Results of CUSUM of Squares test for the ARDL $(5,4,3,2,5)$ model.

Table 6. Results of ARDL Bounds test.

\begin{tabular}{ccc}
\hline \multicolumn{3}{c}{ Bounds Testing for Cointegration } \\
\hline Models & Optimal Lag Length & F-Statistic \\
\hline $\mathrm{F}_{G G D P}($ GGDP/GFCF, FDI, FD, TO) & $2,4,4,4,4$ & $4.49^{* *}$ \\
$\mathrm{~F}_{\text {GNOG }}$ (GNOG/GFCF, FDI, FD, TO) & $5,4,3,2,5$ & $5.76^{*}$ \\
$\mathrm{~F}_{G F C F}(\mathrm{GFCF} / \mathrm{GNOG}$, FDI, FD, TO) & $2,5,2,3,5$ & $7.32^{*}$ \\
$\mathrm{~F}_{F D I}(\mathrm{FDI} / \mathrm{GFCF}$, GGDP, FD, TO) & $1,5,5,0,4$ & $4.46^{* *}$ \\
\hline & Critical Values \\
\hline Significance Level & Lower Bounds I(0) & Upper Bounds I(1) \\
\hline 1\% level & 3.74 & 5.06 \\
$5 \%$ level & 2.86 & 4.01 \\
$10 \%$ level & 2.45 & 3.52 \\
\hline
\end{tabular}

Note: The asterisks *,**, and ${ }^{* * *}$ denote that the variables are cointegrated at $1 \%, 5 \%$, and $10 \%$ levels, respectively. The ARDL models considered do not imply to constrain the intercept and they do not contain linear trend term. The lower and upper bounds at the $1 \%, 5 \%$, and $10 \%$ significance levels are provided directly in the output of the bounds test by the EVIEWS 9 software.

For the long run relationships, we estimate the restricted error correction models to test for the existence of dynamic causal relationships between the various variables. Therefore, we estimate the models given in Equations (5)-(8). The Granger long-run causality between the various variables is determined by the $\mathrm{t}$-significance of the error-correction term $\mathrm{ECT}_{t-1}$ in each equation. The estimates of the coefficients of error-correction terms of models given in Equations (5)-(8), and the long run and short run estimates are reported in Table 7 . The results show that the coefficient of the error-correction term is negative and significant at $1 \%$ level in the four models. These results confirm the existence of the long run relationships between the different variables. They indicate that there are long run bidirectional causality between non-oil GDP growth and FDI, long run bidirectional causality between non-oil GDP growth and domestic capital investment, and long run bidirectional causality between FDI and domestic capital investment. In addition, there is long run unidirectional causality running from FDI, domestic capital investment, finance development, and trade openness to overall GDP growth.

The results of coefficient estimates show that domestic capital investment, FDI inflows, finance development, and trade openness do not affect significantly overall GDP growth in the long run whereas finance development has a negative and significant impact on overall economic growth in the short run for the case of Saudi Arabia. These results are not surprising as economic activities in Saudi Arabia are based on oil production and services. When considering non-oil GDP growth, we find that 
domestic capital investment and FDI inflows affect negatively non-oil GDP growth, both in the short and long terms. Finance development and trade openness have positive and significant impacts on non-oil GDP growth in the long run, but not in the short run. Therefore, finance development and trade openness are supporting non-oil economic growth in the long run. It is recognized that financial development is an important prerequisite for FDI to positively influence economic growth in the long run because the financial system can promote the efficient allocation of resources (Yalta 2013). The negative impact of FDI may be due to the nature of FDI inflows and their instability ${ }^{2}$ in Saudi Arabia. In addition, FDI can affect negatively economic growth in countries having an import substitution strategy, such as Saudi Arabia (Belloumi 2014). According to Balasubramanyam et al. (1996), FDI inward flows are more favorable for economic growth in countries having export-oriented industrialization. Besides, FDI can allow for the technology transfer when the host country has a sufficient stock of human capital (Borensztein et al. 1998). However, this is not the case for Saudi Arabia. The unexpected result of domestic capital investment could be attributed to the structure of the Saudi economy. Even though Saudi government started its development plans since 1975 to diversify its income resources, GDP growth is still linked to oil rents. Another reason for the failure of FDI to positively affect economic growth in Saudi Arabia can be the low levels of the share of FDI in GDP during the majority of the years of the studied period. The share of FDI in GDP has been stabilized to exceed $1 \%$ only since 2005 (UNCTAD 2016). According to Herzer et al. (2008), the low shares of FDI might be marginal to positively affect economic growth.

The results of capital domestic investment and FDI inflows are not conform to theoretical economics literature because they are supposed to increase GDP growth (De Mello 1997). These results conform to those that were obtained in the case of Saudi Arabia by Sadik and Bolbol (2001) over the period of 1978 to 1998 and by Al Khathlan (2013) over the period 1980 to 2010. In addition, our results are conform to those obtained in the case of MENA countries (Darrat et al. 2005; Meschi 2006; Hisarciklilar et al. 2006; Alaya 2006; Nicet-Chenaf and Rougier 2009; Marc 2011; Belloumi 2014).

Table 7. Results of the restricted error correction models.

\begin{tabular}{cccccccccccc}
\hline \multirow{2}{*}{ Dep. Var. } & \multirow{2}{*}{ ECT(-1) } & \multicolumn{4}{c}{ Long Run Coefficients } & \multicolumn{4}{c}{ Short Run Coefficients } \\
\cline { 2 - 12 } & & GNOG & GFCF & FDI & FD & TO & GNOG & GFCF & FDI & FD & TO \\
\hline \multirow{2}{*}{ GGDP } & -1.32 & - & 0.42 & -1.79 & -0.04 & 0.30 & - & 0.53 & -0.09 & -0.79 & 0.09 \\
& $(0.00)$ & & $(0.47)$ & $(0.10)$ & $(0.82)$ & $(0.23)$ & - & $(0.33)$ & $(0.87)$ & $(0.04)$ & $(0.52)$ \\
\hline \multirow{2}{*}{ GNOG } & -1.67 & - & -1.18 & -0.35 & 0.23 & 0.32 & - & -0.64 & -0.27 & -0.06 & 0.11 \\
& $(0.00)$ & & $(0.00)$ & $(0.04)$ & $(0.00)$ & $(0.00)$ & & $(0.00)$ & $(0.18)$ & $(0.57)$ & $(0.11)$ \\
\hline \multirow{2}{*}{ GFCF } & -1.81 & -0.26 & - & -0.04 & 0.27 & 0.14 & -0.26 & & -0.29 & 0.32 & 0.09 \\
& $(0.00)$ & $(0.01)$ & & $(0.76)$ & $(0.00)$ & $(0.01)$ & $(0.00)$ & & $(0.03)$ & $(0.00)$ & $(0.02)$ \\
\hline \multirow{2}{*}{ FDI } & -0.52 & -1.90 & -2.76 & - & 0.37 & 0.76 & -0.27 & -0.13 & - & 0.02 & 0.04 \\
& $(0.00)$ & $(0.01)$ & $(0.01)$ & - & $(0.00)$ & $(0.00)$ & $(0.01)$ & $(0.29)$ & - & $(0.28)$ & $(0.34)$ \\
\hline
\end{tabular}

Non-oil GDP growth affects negatively domestic capital investment in both long and short terms whereas finance development and trade openness have positive and significant effects on domestic capital investment in both terms. FDI inflows affect negatively domestic capital investment in only the short term. It is expected that non-oil GDP growth positively affects domestic capital investment. The result of FDI inflows indicates that FDI crowds out the domestic investment in the short run but not in the long run. This is conform to the finding of Kumar and Pradhan (2002) who showed that FDI inflows negatively affect domestic investment in the short run, but it can have a positive effect in the

2 The volatility of FDI inflows is the result of an absence of reinvestment and the weak integration of foreign firms in Saudi Arabia. 
long run due to the generation of accumulated linkages. Finance development and trade openness are promoting domestic capital investment.

Finally, non-oil GDP growth negatively affects FDI inflows in both terms, whereas domestic investment has a negative and significant impact on FDI inflows in only the long term. Finance development and trade openness have positive impacts on domestic capital investment only in the long run. The result of non-oil GDP growth is unexpected and it is not conform to theoretical economics literature. The result of domestic capital investment indicates that it crowds out FDI inflows in the long run. A greater openness and more credits accorded to private sector are favorable for FDI inflows attraction in Saudi Arabia.

\subsection{Robustness of the Results}

In order to test the sensitive nature of the long run causal relationships between economic growth, domestic capital investment, and FDI to the method used, we re-estimate the long run relationships using the fully modified ordinary least squares (FMOLS), dynamic ordinary least squares (DOLS), and canonical cointegrating regression (CCR) methods. Table 8 reports their results with some diagnostic tests. Overall, the results of Jarque-Bera, Philipps-Ouliaris and Engle-Granger tests show that all the estimates obtained are reliable. Besides, the FMOLS, DOLS, and CCR estimates are conform to those obtained by ARDL models. Therefore, our results are robust.

Table 8. Long run estimates by the fully modified ordinary least squares (FMOLS), dynamic ordinary least squares (DOLS), and the canonical cointegrating regression (CCR).

\begin{tabular}{|c|c|c|c|c|c|c|c|c|c|c|c|c|}
\hline \multirow{2}{*}{$\begin{array}{c}\text { Indep. } \\
\text { Variables }\end{array}$} & \multicolumn{3}{|c|}{ Equation (1) } & \multicolumn{3}{|c|}{ Equation (2) } & \multicolumn{3}{|c|}{ Equation (3) } & \multicolumn{3}{|c|}{ Equation (4) } \\
\hline & FMOLS & DOLS & CCR & FMOL & DOLS & CCR & FMOLS & DOLS & CCR & FMOLS & DOLS & CCR \\
\hline GGDP/GNOG & - & - & - & - & - & - & $\begin{array}{l}-0.41 \\
(0.00)\end{array}$ & $\begin{array}{l}-0.35 \\
(0.03)\end{array}$ & $\begin{array}{l}-0.49 \\
(0.00)\end{array}$ & $\begin{array}{l}-0.09 \\
(0.49)\end{array}$ & $\begin{array}{l}-0.12 \\
(0.67)\end{array}$ & $\begin{array}{l}-0.19 \\
(0.10)\end{array}$ \\
\hline GFCF & $\begin{array}{l}-1.14 \\
(0.00)\end{array}$ & $\begin{array}{l}-8.72 \\
(0.01)\end{array}$ & $\begin{array}{l}-0.86 \\
(0.00)\end{array}$ & $\begin{array}{l}-0.76 \\
(0.00)\end{array}$ & $\begin{array}{l}-0.92 \\
(0.01)\end{array}$ & $\begin{array}{l}-0.89 \\
(0.00)\end{array}$ & - & - & - & $\begin{array}{l}-0.17 \\
(0.03)\end{array}$ & $\begin{array}{l}-0.07 \\
(0.87)\end{array}$ & $\begin{array}{l}-0.05 \\
(0.73)\end{array}$ \\
\hline FDI & $\begin{array}{l}-1.35 \\
(0.00)\end{array}$ & $\begin{array}{l}-5.11 \\
(0.26)\end{array}$ & $\begin{array}{l}-1.62 \\
(0.00)\end{array}$ & $\begin{array}{l}-0.49 \\
(0.00)\end{array}$ & $\begin{array}{l}-0.85 \\
(0.29)\end{array}$ & $\begin{array}{l}-0.39 \\
(0.02)\end{array}$ & $\begin{array}{c}0.23 \\
(0.08)\end{array}$ & $\begin{array}{l}-0.39 \\
(0.38)\end{array}$ & $\begin{array}{c}0.09 \\
(0.63)\end{array}$ & - & - & - \\
\hline FD & $\begin{array}{c}0.15 \\
(0.36)\end{array}$ & $\begin{array}{c}0.66 \\
(0.24)\end{array}$ & $\begin{array}{l}-0.05 \\
(0.70)\end{array}$ & $\begin{array}{c}0.10 \\
(0.01)\end{array}$ & $\begin{array}{c}0.36 \\
(0.00)\end{array}$ & $\begin{array}{c}0.15 \\
(0.00)\end{array}$ & $\begin{array}{c}0.23 \\
(0.00)\end{array}$ & $\begin{array}{c}0.08 \\
(0.22)\end{array}$ & $\begin{array}{c}0.21 \\
(0.00)\end{array}$ & $\begin{array}{c}0.18 \\
(0.00)\end{array}$ & $\begin{array}{c}0.10 \\
(0.01)\end{array}$ & $\begin{array}{c}0.19 \\
(0.00)\end{array}$ \\
\hline TO & $\begin{array}{c}0.17 \\
(0.06)\end{array}$ & $\begin{array}{c}3.44 \\
(0.01)\end{array}$ & $\begin{array}{c}0.13 \\
(0.21)\end{array}$ & $\begin{array}{c}0.31 \\
(0.00)\end{array}$ & $\begin{array}{c}0.38 \\
(0.00)\end{array}$ & $\begin{array}{c}0.32 \\
(0.00)\end{array}$ & $\begin{array}{c}0.12 \\
(0.00)\end{array}$ & $\begin{array}{c}0.31 \\
(0.00)\end{array}$ & $\begin{array}{c}0.18 \\
(0.00)\end{array}$ & $\begin{array}{c}0.10 \\
(0.01)\end{array}$ & $\begin{array}{c}0.16 \\
(0.25)\end{array}$ & $\begin{array}{c}0.10 \\
(0.08)\end{array}$ \\
\hline \multicolumn{13}{|c|}{ Diagnostic tests } \\
\hline R squared & 0.44 & 0.95 & 0.43 & 0.64 & 0.93 & 0.64 & 0.64 & 0.96 & 0.60 & 0.36 & 0.89 & 0.37 \\
\hline J-B stat & $\begin{array}{c}0.21 \\
(0.90)\end{array}$ & $\begin{array}{c}2.54 \\
(0.28)\end{array}$ & $\begin{array}{c}0.55 \\
(0.75)\end{array}$ & $\begin{array}{l}200.1 \\
(0.00)\end{array}$ & $\begin{array}{c}5.33 \\
(0.07)\end{array}$ & $\begin{array}{l}167.9 \\
(0.00)\end{array}$ & $\begin{array}{c}8.17 \\
(0.01)\end{array}$ & $\begin{array}{c}0.72 \\
(0.69)\end{array}$ & $\begin{array}{c}5.14 \\
(0.07)\end{array}$ & $\begin{array}{c}3.64 \\
(0.16)\end{array}$ & $\begin{array}{c}3.60 \\
(0.16)\end{array}$ & $\begin{array}{c}3.15 \\
(0.20)\end{array}$ \\
\hline $\begin{array}{c}\text { Philipps } \\
\text { Ouliaris } \tau \text { stat }\end{array}$ & $\begin{array}{l}-7.50 \\
(0.00)\end{array}$ & $\begin{array}{l}-7.53 \\
(0.00)\end{array}$ & $\begin{array}{l}-7.37 \\
(0.00)\end{array}$ & $\begin{array}{l}-6.48 \\
(0.00)\end{array}$ & $\begin{array}{l}-6.40 \\
(0.00)\end{array}$ & $\begin{array}{l}-6.40 \\
(0.00)\end{array}$ & $\begin{array}{l}-4.02 \\
(0.17)\end{array}$ & $\begin{array}{l}-3.44 \\
(0.39)\end{array}$ & $\begin{array}{l}-4.02 \\
(0.17)\end{array}$ & $\begin{array}{l}-4.43 \\
(0.08)\end{array}$ & $\begin{array}{l}-4.50 \\
(0.07)\end{array}$ & $\begin{array}{l}-4.43 \\
(0.08)\end{array}$ \\
\hline $\begin{array}{c}\text { Engle-Granger } \\
\tau \text { stat }\end{array}$ & $\begin{array}{l}-7.33 \\
(0.00)\end{array}$ & $\begin{array}{l}-7.38 \\
(0.00)\end{array}$ & $\begin{array}{l}-7.23 \\
(0.00)\end{array}$ & $\begin{array}{l}-6.31 \\
(0.00)\end{array}$ & $\begin{array}{l}-6.25 \\
(0.00)\end{array}$ & $\begin{array}{l}-6.25 \\
(0.00)\end{array}$ & $\begin{array}{l}-4.03 \\
(0.17)\end{array}$ & $\begin{array}{l}-3.52 \\
(0.36)\end{array}$ & $\begin{array}{l}-4.03 \\
(0.17)\end{array}$ & $\begin{array}{l}-4.38 \\
(0.09)\end{array}$ & $\begin{array}{l}-4.47 \\
(0.08)\end{array}$ & $\begin{array}{l}-4.38 \\
(0.09)\end{array}$ \\
\hline
\end{tabular}

\section{Conclusions and Policy Implications}

This study in interesting for policy makers in Saudi Arabia to undertake the effective policies that can promote and lead FDI inward flows to enhance economic growth in the country. It analyses the causal links between domestic capital investment, FDI, and economic growth in Saudi Arabia over the period 1970-2015 by using the ARDL bounds testing to cointegration approach. The FMOLS, DOLS, and CCR are employed to check the robustness of the ARDL long run estimates. We find that the results are the same for the different estimation techniques. Overall, our findings show that 
in the long term there are negative bidirectional causality between non-oil GDP growth and FDI, negative bidirectional causality between non-oil GDP growth and domestic capital investment, and bidirectional causality between FDI and domestic capital investment. FDI affects negatively domestic capital investment in the short run whereas domestic capital investment affects negatively FDI in the long run. Hence, FDI inflows crowd out domestic investment only the short term. Both finance development and trade openness affect positively non-oil GDP growth, FDI inflows, and domestic capital investment in the long run. Therefore, the Saudi economic growth is relying on trade openness and domestic credits accorded to private sector.

These results lead to some policy implications. Firstly, it is shown that GDP growth in Saudi Arabia is not mainly linked to investments (domestic and foreign). Secondly, the Saudi government should give more attention to the nature of domestic and foreign investments. It should orient its domestic and foreign investments to more productive projects that promote economic growth. Thirdly, Saudi Arabia should diversify its economic activities to be more independent from oil rents. Therefore, it should create an environment that attracts the kinds of domestic and foreign investments that can boost economic growth. Finally, Saudi decision makers should stabilize FDI inflows to have a sufficient amount that can promote non-oil activities based on export-oriented industrialization. The most important sectors eligible to contribute effectively in the development and diversification of the economic base of Saudi Arabia are diverse. As examples, we can cite the development and promotion of tourism activities, the increase of the participation of women in the labor market, the development of the Saudi military industry through the establishment of a holding company for military industries, development of the petroleum, gas and petrochemicals industries, the development of the mining sector as Saudi Arabia has the largest mineral wealth in the Gulf region, development of textile industry by expanding the production of synthetic fibers petrochemical manufacturer, development of insurance sector because this sector still faces some obstacles, such as the absence of a system of insurance and a poor awareness of its significance, development of pharmaceutical industries, development of information technology industry, etc.

This study can be improved in at least three directions. Firstly, an extension is always important to include a larger sized database including additional variables. Secondly, the effectiveness of FDI in affecting economic growth does not depend on only the level of FDI, but its nature and the sectors of investment involved. Finally, a study using disaggregated data for different sectors according to the nature of FDI could give better findings.

Acknowledgments: The study is not funded by any organization.

Author Contributions: Mounir Belloumi obtained and analyzed the data using econometric techniques. Both authors discussed the results and wrote the paper.

Conflicts of Interest: The authors declare no conflict of interest.

\section{References}

Adams, Samuel. 2009. Foreign Direct investment, domestic investment, and economic growth in Sub-Saharan Africa. Journal of Policy Modeling 31: 939-49. [CrossRef]

Akinlo, A. Enisan. 2004. Foreign direct investment and economic growth in Nigeria: An empirical investigation. Journal of Policy Modeling 26: 627-39. [CrossRef]

Al Khathlan, Khalid. 2013. Foreign Direct Investment Inflows and Economic Growth in Saudi Arabia: A Co-integration Analysis. Review of Economics and Finance 4: 70-80.

Al khatib, Hazem, Gassan Altaleb, and Samer Alokor. 2012. Economical determinants of domestic investment. European Scientific Journal 8: 1-17.

Alaya, Marouane. 2006. Investissement direct étranger et croissance économique: Une estimation à partir d'un modèle structurel pour les pays de la rive sud de la Méditerranée. Paper presented at the 7èmes Journées Scientifiques du Réseau “Analyse Economique et Développement de l'AUF”, Paris, France, September 7-8.

Alguacil, Maite, Ana Cuadros, and Vicente Orts. 2002. Foreign direct investment, exports and domestic performance in Mexico: A causality analysis. Economic Letters 77: 371-76. [CrossRef] 
Arrow, Kenneth. 1962. Economic Welfare and the Allocation of Resources for Invention. In The Rate and Direction of Inventive Activity: Economic and Social Factors. Princeton: Princeton University Press.

Balasubramanyam, Vudayagiri N., Mohammed Salisu, and David Sapsford. 1996. Foreign direct investment and the growth in EP and IS countries. Economic Journal 106: 92-105. [CrossRef]

Balasubramanyam, Vudayagiri N., Mohammed Salisu, and David Sapsford. 1999. Foreign direct investment as an engine of growth. Journal of International Trade and Economic Development 8: 27-40. [CrossRef]

Bayar, Yilmaz. 2014. Effects of Foreign Direct Investment Inflows and Domestic Investment on Economic Growth: Evidence from Turkey. International Journal of Economics and Finance 6: 69-78. [CrossRef]

Belloumi, Mounir. 2014. The relationship between trade, FDI and economic growth in Tunisia: An application of the autoregressive distributed lag model. Economic Systems 38: 269-87. [CrossRef]

Belloumi, Mounir, and Atef Saad Alshehry. 2015. Sustainable energy development in Saudi Arabia. Sustainability 7: 5153-70. [CrossRef]

Belloumi, Mounir, and Atef Saad Alshehry. 2016. The Impact of Urbanization on Energy Intensity in Saudi Arabia. Sustainability 8: 375-85. [CrossRef]

Borensztein, Eduardo, José de Gregorio, and Jong-Wha Lee. 1998. How does foreign direct investment affect economic growth? Journal of International Economics 45: 115-35. [CrossRef]

Boyd, John H., and Bruce D. Smith. 1992. Intermediation and the equilibrium allocation of investment capital: Implications for economic development. Journal of Monetary Economics 30: 409-32. [CrossRef]

Chandana, Chakraborty, and Basu Parantap. 2002. Foreign direct investment and growth in India: A cointegration approach. Applied Economics 34: 1061-73. [CrossRef]

Choi, Yoon Jung, and Jungho Baek. 2017. Does FDI Really Matter to Economic Growth in India? Economies 5: 20. [CrossRef]

Darrat, Ali F., Samer Kherfi, and Mark Soliman. 2005. FDI and economic growth in CEE and MENA countries: A tale of two regions. Paper presented at The 12th Economic Research Forum's Annual Conference, Cairo, Egypt, December 19-21.

De Mello, Luzi R. 1997. Foreign direct investment in developing countries: A selective survey. Journal of Development Studies 34: 1-34. [CrossRef]

De Mello, Luiz R. 1999. Foreign direct investment-led growth: Evidence from time series and panel data. Oxford Economic Papers 51: 133-51. [CrossRef]

Dickey, David, and Wayne Fuller. 1979. Distribution of the Estimators for Autoregressive Time Series with a Unit Root. Journal of the American Statistical Association 74: 427-31.

Dritsaki, Melina, Chaido Dritsaki, and Antonios Adamopoulos. 2004. A Causal Relationship between Trade, Foreign Direct Investment and Economic Growth for Greece. American Journal of Applied Science 1: 230-35. [CrossRef]

Durham, J. Benson. 2004. Absorptive capacity and the effects of foreign direct investment and equity foreign portfolio investment on economic growth. European Economic Review 84: 285-306. [CrossRef]

Eller, Markus, Peter R. Haiss, and Katharina Steiner. 2005. Foreign Direct Investment in the Financial Sector: The Engine of Growth for Central and Eastern Europe? Europa Institute Working Paper No. 69. Vienna: Vienna University of Economics and Business Administration.

Elliott, Graham, Thomas Rothenberg, and James Stock. 1996. Efficient Tests for an Autoregressive Unit Root. Econometrica 64: 813-36. [CrossRef]

Elsadig, Musa Ahmed. 2012. Are the FDI inflow spillover effects on Malaysia's economic growth input driven? Economic Modelling 29: 1498-504.

Fabry, Nathalie, and Sylvain Zeghni. 2002. Foreign direct investment in Russia: How the investment climate matters. Communist and Post-Communist Studies 35: 289-303. [CrossRef]

Firebaugh, Glenn. 1992. Growth Effects of Foreign and Domestic Investment. American Journal of Sociology 98: 105-30. [CrossRef]

Ghali, Khalifa H., and Ahmed Al-Mutawa. 1999. The Intertemporal Causal Dynamics between Fixed Capital Formation and Economic Growth in the Group-of-Seven Countries. International Economic Journal 13: 31-37.

Ghirmay, Teame, Richard Garbowski, and Subhash Sharma. 2001. Exports, investment efficiency and economic growth in LDC: An empirical investigation. Applied Economics 33: 689-700. [CrossRef]

Grossman, Gene, and Elhanan Helpman. 1994. Endogenous Innovation in the Theory of Growth. The Journal of Economic Perspectives 8: 23-44. [CrossRef] 
Herzer, Dierk, Stephan Klasen, and Felicitas Lehmann. 2008. In search of FDI-led growth in developing countries: The way forward. Economic Modelling 25: 793-810. [CrossRef]

Hisarciklilar, Mehtap, Saime S. Kayam, Ozgur M. Kayalica, and N. L. Ozkale. 2006. Foreign direct investment and growth in Mediterranean countries. Paper presented at the Jean Monnet Project on "Sustainable Development and Adjustment in the MEDA Countries Following the EU Enlargement", Spetses Island, Greece, July 3-5; Available online: http:/ / emo.pspa.uoa.gr/data/papers/2_paper.pdf (accessed on 17 June 2017).

Hussain, Mohammed Ershad, and Mahfuzul Haque. 2016. Foreign Direct Investment, Trade, and Economic Growth: An Empirical Analysis of Bangladesh. Economies 4: 7. [CrossRef]

Iamsiraroj, Sasi. 2016. The foreign direct investment-economic growth nexus. International Review of Economics and Finance 42: 116-33. [CrossRef]

Iya, Ibriya, and Umaru Aminu. 2015. An Investigation into the Impact of Domestic Investment and Foreign Direct Investment on Economic Growth in Nigeria. International Journal of Humanities Social Sciences and Education 2: $40-50$.

Johansen, Soren. 1995. Likelihood-Based Inference in Cointegrated Vector Autoregressive Models. New York: Oxford University Press.

Johansen, Soren, and Katarina Juselius. 1990. Maximum Likelihood Estimation and Inference on Cointegration-With Applications to the Demand for Money. Oxford Bulletin of Economics and Statistics 52: 169-210. [CrossRef]

Khawar, Mariam. 2005. Foreign Direct Investment and Economic Growth: A Cross-Country Analysis. Global Economy Journal 5: 1-14. [CrossRef]

Kowalski, Elizabeth. 2000. Determinants of Economic Growth in East Asia: A Linear Regression Model. Honors Projects 74. Available online: https:/ / digitalcommons.iwu.edu/econ_honproj/74/ (accessed on 27 January 2018).

Kumar, Nages, and Jaya Prakash Pradhan. 2002. FDI, Externalities, and Economic Growth in Developing Countries: Some Empirical Explorations and Implications for WTO Negotiations on Investment. RIS Discussion Paper No. 27/2002. New Delhi: Research and Information System for Developing Countries.

Lean, Hooi Hooi, and Bee Wah Tan. 2011. Linkages between foreign direct investment, domestic investment and economic growth in Malaysia. Journal of Economic Cooperation and Development 32: 75-96.

Lensink, Robert, and Oliver Morrissey. 2006. Foreign Direct Investment: Flows, Volatility, and the Impact on Growth. Review of International Economics 14: 478-93. [CrossRef]

Li, Xiaoying, and Xiaming Liu. 2005. Foreign Direct Investment and Economic Growth: An Increasingly Endogenous Relationship. World Development 33: 393-407. [CrossRef]

Liu, Xiaohui, Peter Burridge, and Paul J. N. Sinclair. 2002. Relationships between economic growth, foreign direct investment and trade: Evidence from China. Applied Economics 34: 1433-40. [CrossRef]

Lucas, Robert. 1988. On the mechanics of economic development. Journal of Monetary Economics 22: 3-42. [CrossRef]

Marc, Audi. 2011. Is foreign direct investment a cure for economic growth in developing countries? Structural model estimation applied to the case of the south shore Mediterranean countries. Journal of International Business and Economics 11: 32-51.

Meschi, Elena. 2006. FDI and growth in MENA countries: An empirical analysis. Paper presented at The Fifth International Conference of the Middle East Economic Association, Sousse, Tunisia, March 10-12.

Moses, Ekperiware C. 2011. Oil and nonoil FDI and economic growth in Nigeria. Journal of Emerging Trends in Economics and Management Sciences 2: 333-43.

Narayan, Paresh. 2005. The saving and investment nexus for China: evidence from cointegration tests. Applied Economics 37: 1979-90. [CrossRef]

Nicet-Chenaf, Dalila, and Eric Rougier. 2009. FDI and Growth: A New Look at a Still Puzzling Issue. Working Paper GREThA number 2009-13. Bordeaux: University of Bordeaux.

Omonkhanlen, Enisan A. 2011. Foreign direct investment and its effect on the Nigerian economy. Business Intelligence Journal 4: 253-61.

Omri, Anis, and Bassem Kahouli. 2014. The nexus among foreign investment, domestic capital and economic growth: Empirical evidence from the MENA region. Research in Economics 68: 257-63. [CrossRef]

Ozturk, Ilhan. 2007. Foreign Direct Investment-Growth Nexus: A Review of Literature. International Journal of Applied Econometrics and Quantitative Studies 4: 79-98. 
Perron, Pierre. 1989. The great crash, the oil price shock, and the unit root hypothesis. Econometrica 57: $1361-401$. [CrossRef]

Pesaran, Hashem, and Yongcheol Shin. 1999. An Autoregressive Distributed Lag Modelling Approach to Cointegration Analysis. In Econometrics and Economic Theory in the 20th Century: The Ragnar Frisch Centennial Symposium. Edited by S. Strom. Cambridge: Cambridge University Press.

Pesaran, Hashem, Yongcheol Shin, and Richard Smith. 2001. Bounds testing approaches to the analysis of level relationships. Journal of Applied Econometrics 16: 289-326. [CrossRef]

Phillips, Peter, and Pierre Perron. 1988. Testing for a unit root in time series regression. Biometrika 75: $335-46$. [CrossRef]

Qin, Duo, Marie Anne Cagas, Pilipinas Quising, and Xin-Hua He. 2006. How much does Investment Drive Economic Growth in China? Journal of Policy Modelling 28: 751-74. [CrossRef]

Ridzuan, Abdul Rahim, Nor Asmat Ismail, and Abdul Fatah Che Hamat. 2017. Does Foreign Direct Investment Successfully Lead to Sustainable Development in Singapore? Economies 5: 29. [CrossRef]

Romer, Paul. 1986. Increasing Returns and Long-Run Growth. Journal of Political Economy 94: 1002-37. [CrossRef]

Romer, Paul. 1990. Endogenous Technological Change. Journal of Political Economy 98: 71-102. [CrossRef]

Roy, Samrat, and Kolkata Kumarjit Mandal. 2012. Foreign direct investment and economic growth: An analysis for selected Asian Countries. Journal of Business Studies Quarterly 4: 15-24.

Ruranga, Charles, Bruno Ocaya, and William Kaberuka. 2014. VAR Analysis of Economic Growth, Domestic Investment, Foreign Direct Investment, Domestic Savings and Trade in Rwanda. Greener Journal of Economics and Accountancy 3: 30-41.

Sadik, Ali T., and Ali Bolbol. 2001. Capital flows, FDI, and technology spillovers: Evidence from Arab countries. World Development 29: 2111-25. [CrossRef]

Sekmen, Fuat. 2007. Cointegration and causality among foreign direct investment in tourism sector, GDP, and exchange rate volatility in Turkey. The Empirical Economics Letters 6: 52-58.

Shell, Karl. 1966. Toward a theory of inventive activity and capital accumulation. American Economic Review 56: 62-68.

Tahir, Muhammad, Imran Khan, and Afzal Moshadi Shah. 2015. Foreign Remittances, Foreign Direct Investment, Foreign Imports and Economic Growth in Pakistan: A Time Series Analysis. Arab Economic and Business Journal 10: 82-89. [CrossRef]

Tang, Sumei, Eliyathamby Antony Selvanathan, and Saroja Selvanathan. 2008. Foreign direct investment, domestic investment and economic growth in China: A time series analysis. The World Economy 31: 1292-309. [CrossRef]

Temiz, Dilek, and Aytaç Gokmen. 2014. FDI inflow as an international business operation by MNCs and economic growth: An empirical study on Turkey. International Business Review 23: 145-54. [CrossRef]

Thangavelu, Shandre, Yik Wei Yong, and Aekapol Chongvilavian. 2009. FDI, growth and the Asian financial crisis: The experience of selected Asian countries. The World Economy 32: 1461-77. [CrossRef]

Tintin, Cem. 2012. Does foreign direct invest spur economic growth and development? A comparative study. Paper presented at The 14th Annual European Trade Study Group Conference, Leuven, Belgium, September 13-15.

UNCTAD. 2016. United Nations Conference on Trade and Development Statistics. Available online: http:/ / unctadstat.unctad.org/wds/ReportFolders/reportFolders.aspx?sCS_ChosenLang=en (accessed on 10 May 2017).

Villa, Stefania. 2008. Economic growth, investment and government consumption in Italy: A VAR analysis. ICFAI Journal of Applied Economics 7: 23-32.

World Bank. 2016. World Development Indicators. Washington: World Bank.

Yalta, Yasemin A. 2013. Revisiting the FDI-led growth Hypothesis: The case of China. Economic Modelling 31: 335-43. [CrossRef]

(c) 2018 by the authors. Licensee MDPI, Basel, Switzerland. This article is an open access article distributed under the terms and conditions of the Creative Commons Attribution (CC BY) license (http:/ / creativecommons.org/licenses/by/4.0/). 